\title{
First Record of Baseodiscus bempricbii (Nemertea: Baseodiscidae) on Easter Island (Rapa Nui) and a New Eastern Distribution Boundary for the Species ${ }^{1}$
}

\author{
Christopher B. Boyko ${ }^{2}$
}

\begin{abstract}
A single specimen of the nemertean Baseodiscus bemprichii (Ehrenberg, 1831) was collected from Easter Island during August 1999. This represents the first record of the species on Easter Island, the first identified nemertean from that island, and extends the eastern boundary of the species' range by approximately $4800 \mathrm{~km}$.
\end{abstract}

The small South Pacific landmass of Easter Island, or Rapa Nui, is situated nearly $3800 \mathrm{~km}$ from the South American mainland and over $2200 \mathrm{~km}$ from Pitcairn Island, its nearest neighbor to the west. All of the marine fauna shows affinities to the Indo-Pacific, although the water temperatures of 17.5$24^{\circ} \mathrm{C}$ are relatively cool (DiSalvo et al. 1988). All available data indicate that the marine invertebrate fauna of Easter Island is depauperate compared with other islands of the tropical Pacific (Rehder 1980, Massin 1996), but it has a high percentage of endemic taxa (e.g., 36\% for Mollusca, 39\% for Porifera [unpubl. data]). It is therefore considered its own biogeographic province along with tiny Sala y Gómez, $415 \mathrm{~km}$ to the east (Briggs 1974). On Easter Island, however, specimens of only eight invertebrate phyla have been identified to the species level to date. A single specimen of nemertean was collected during

${ }^{1}$ Funding for the Invertebrate Survey of Easter Island was provided by the U.S. National Park Service, Gateway National Recreation Area, Division of Natural Resources, as part of a Science Museum of Long Island/Explorers Club 5-yr research expedition to explore the impacts of El Niño events on World Heritage Sites. Manuscript accepted 25 April 2000.

${ }^{2}$ Division of Invertebrate Zoology, American Museum of Natural History, Central Park West at 79th Street, New York, New York 10024, and Department of Biological Sciences, University of Rhode Island, Kingston, Rhode Island 02881 (E-mail: cboyko@amnh.org).

Pacific Science (2001), vol. 55, no. 1:41-42

(C) 2001 by University of Hawai'i Press

All rights reserved
August 1999 as part of an invertebrate survey of Easter Island. It was subsequently readily identified as Baseodiscus bempricbii (Ehrenberg, 1831) on the basis of its distinctive color pattern. This represents not only the first record of the species on Easter Island, but extends the eastern boundary of the species' range by approximately $4800 \mathrm{~km}$. Although nemerteans have been recorded as occurring on Easter Island (DiSalvo et al. 1988), this is the first identification of any specimen to the species level. The specimen is deposited in the American Museum of Natural History, New York (AMNH).

\section{Family Baseodiscidae Bürger, 1907 Genus Baseodiscus Diesing, 1850}

Baseodiscus hemprichii (Ehrenberg, 1831) Figure 1

Nemertes Hempricbii Ehrenberg, 1831:12-13. Baseodiscus hemprichii: Gibson, 1979:146-153 (synonymy).

MATERIAL EXAMINED: Under lava boulder, intertidal zone, Anakena, Easter Island (Rapa Nui), Chile, 30 August 1999, coll. C. B. Boyko and S. Reanier: 1 specimen, $25 \mathrm{~cm}$ length (AMNH 1512).

DISTRIBUTION: This species has a broad Indo-Pacific distribution and is known from the Red Sea to the Hawaiian Islands. This range is now extended southeastward to Easter Island.

REMARKs: The Easter Island specimen had a white ground color with a single median stripe of purple along the dorsal margin 


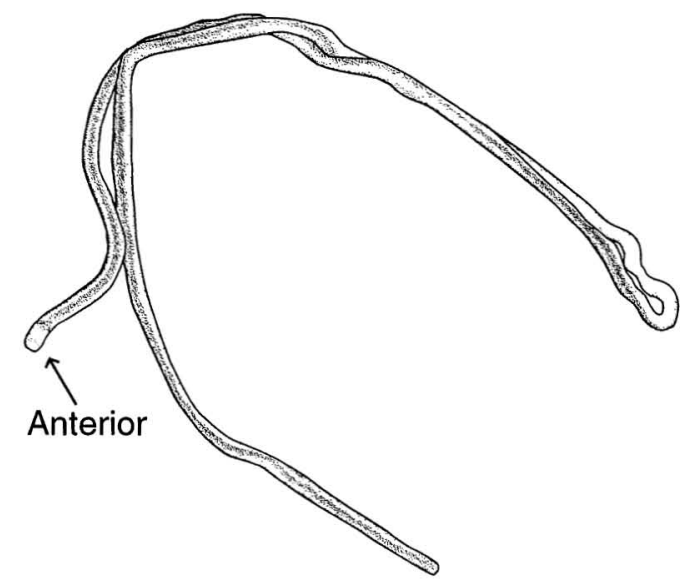

FIgURE 1. Specimen of Baseodiscus hemprichii (Ehrenberg, 1831) from Anakena, Easter Island (Rapa Nui), $25 \mathrm{~cm}$ length (АMNH 1512). Dorsal view. Drawing from color transparency deposited in AMNH.

and a similar but thinner stripe along the ventral margin. The dorsal stripe forms a collar just posterior to the head and there is an additional incomplete band of purple on the dorsal cephalic surface. The Easter Island specimen most closely resembles one figured by Gibson (1979: fig. 5d) in terms of color pattern. Although some variability in color exists in this species, Gibson (1979) maintained that this taxon could be unambiguously identified by the color pattern alone. This species, like most other Baseodiscus, has a weakly developed proboscis (Gibson 1979).

Although some authors (DiSalvo et al. 1988) have suggested that species known only from single specimens on Easter Island may occur as chance dispersals from western populations, the data available on the prevailing unidirectional east-west ocean current flow appear to refute the likelihood of this happening frequently (Rehder 1980, Massin 1996). More likely, these "rare" taxa are actually living in low-density established populations or in unexplored habitats. Indeed, the locality data for the specimen of $B$. bemprichii support this, because it was collected from the underside of a large lava boulder in the intertidal zone that was positioned in a way that made overturning it relatively simple. Most similarly sized rocks are too heavy to move and examine the lower surfaces, where the highest concentration of invertebrate fauna reside. Baseodiscus bemprichii is probably well established on Easter Island, and further sampling targeted at nemerteans will undoubtedly yield more specimens of this taxon and additional nemertean species.

\section{ACKNOWLEDGMENTS}

I thank John Tanacredi (U.S. National Park Service, Gateway) for inviting me to participate in this survey. Paula Mikkelsen (AMNH) kindly reviewed an early draft of this paper.

\section{Literature Cited}

Briggs, J. C. 1974. Marine zoogeography. McGraw-Hill, New York. 475 pp.

Bürger, O. 1907. Nemertini (Schnurwürmer). In H. G. Bronn, ed. Klassen und Ordnungen des Tier-Reichs, Suppl. 4 (28-29): 433-464.

Diesing, C. M. 1850. Systema Helminthum. Vol. I. W. Braumüller, Vindobonae. 680 pp.

DiSalvo, L. H., J. E. Randall, and A. Cea. 1988. Ecological reconnaissance of the Easter Island sublittoral marine environment. Natl. Geogr. Res. 4 (4): 451-473.

Ehrenberg, C. G. 1831. Symbolae Physicae Seu Icones et Descriptiones Corporum Naturalium Novorum aut Minus Cognitorum quae ex Itineribus per Libyam, Aegyptum, Nubiam, Dongalam, Syriam, Arabiam et Habessiniam. Pars Zoologica II(2). Animalia Evertebrata. Phytozoa Turbellaria Africana et Asiatica. G. Reimeri, Berlin. 16 pp., pls. 4, 5.

Gibson, R. 1979. Nemerteans of the Great Barrier Reef 2. Anopla Heteronemertea (Baseodiscidae). Zool. J. Linn. Soc. (Lond.) 66 (2): 137-160.

Massin, C. 1996. The holothurians of Easter Island. Bull. Inst. R. Sci. Nat. Belg. 66: 151-178.

Rehder, H. A. 1980. The marine mollusks of Easter Island (Isla de Pascua) and Sala y Gómez. Smithson. Contrib. Zool. 289. $167 \mathrm{pp}$. 